\title{
УНИВЕРЗИТЕТСКА НАСТАВА ЈУЖНОСЛОВЕНСКИХ ЈЕЗИКА У СРБИЈИ - ИСТОРИЈАТ И МОГУЋИ ПРАВЦИ РАЗВОЈА
}

\section{Сажетак}

У раду је представљен статус словеначког, македонског и бугарског језика, са освртом на положај осталих језика који су заступљени у оквиру националних мањина у Србији. Полазећи од историјата наставе јужнословенских језика у Србији, од почетка XX века наовамо, кроз сагледавање њиховог положаја у оквиру других страних језика, представљене су сличности и разлике у развоју наставе ових језика у Србији. Посебан нагласак је стављен на представљање могућности развоја наставе јужнословенских језика, пре свега на универзитетском нивоу, са свим специфичностима које прате њихов статус и међусобни однос.

Кључне речи: јужнословенски језици, настава страних језика, мањински језици.

\section{1. Увод}

УРепублици Србији, каомултинационалнојзаједници, живемноги народи, који говоре различитим језицима. Поред Срба, најбројнији су Мађари (најзаступљенији су у Региону Војводине), затим Роми (Регион јужне и источне Србије и Регион Војводине) и Бошњаци (претеж-

\footnotetext{
* borko.kovacevic@fil.bg.ac.rs

**\$maja.djukanovic@fil.bg.ac.rs

*** Филолошки факултет, Студентски трг 3, 11000 Београд
} 
но живе у Региону Шумадије и западне Србије). Према Републичком заводу за статистику, по попису становништва из 2011. године, Срба има 5.988.150, Албанаца 5.809, Бошњака 145.278, Бугара 18.543, Буњеваца 16.706, Влаха 35.330, Горанаца 7.767, Југословена 23.303, Мађара 253.899, Македонаца 22.755, Муслимана 22.301, Немаца 4.064, Рома 147.604, Румуна 29.332, Руса 3.247, Русина 14.246, Словака 52.750, Словенаца 4.033, Украјинаца 4.903, Хрвата 57.900, Црногораца 38.527 и осталих 17.558. Многи од језика ових националних заједница на регионалном и локалном нивоу, као мањински језици, функционишу у службеној употреби. Ради остварења права на самоуправу у култури, образовању, обавештавању и службеној употреби језика и писма, припадници националних мањина у Републици Србији имају развијене могућности за учење матерњег језика. ${ }^{1}$

Јужнословенски језици (словеначки, бугарски и македонски) ${ }^{2}$ увек су ипак имали посебан статус у односу на све друге данас признате мањинске језике. Ту се пре свега мисли на словеначки и македонски, који су (као и српски, односно тада српскохрватски) били језици у службеној употреби у некадашњој Социјалистичкој Федеративној Републици Југославији. На посебан статус ова три језика свакако је утицала и чињеница да се ради о генетски најсроднијим језицима српском језику, због чега су увек били ,ммање страни“ у односу на друге стране језике. Историја изучавања и могући даљи правци развоја јужнословенских језика у Србији предмет су овог рада.

\section{2. Досадашње изучавање јужнословенских језика у Србији}

Словеначки, македонски и бугарски језик одувек су у погледу њиховог изучавања имали специфичан статус у односу на друге стра-

1 Припадници националних мањина у Србији имају и могућност стварања, односно бирања својих националних савета. О могућностима за развијање и неговање националне свести, укључујући и учење матерњег језика, пре свега на примеру Словенаца и словеначког језика у Србији в. Буквич (2016).

2 Не улазећи у природу њиховог статуса, овде се не разматрају хрватски и евентуално бошњачки/босански и црногорски, као део јужнословенског говорног подручја, из разлога што традицију изучавања у школском систему Србије, а пре свега на универзитетском нивоу, имају само ова три јасно издвојена језика (словеначки, бугарски и македонски). 
не језике у Србији. На Филолошком факултету у Београду ови језици се изучавају при катедри за српски језик, чији је пуни назив Катедра за српски језик са јужнословенским језицима. ${ }^{3}$

Како стоји на сајту Катедре, према традиционалној структури, Катедра је носилац научних истраживања и наставе не само спрског језика, него и осталих јужнословенских језика (словеначки, македонски и бугарски). После II светског рата проф. Михаило Стевановић предаје македонски језик, а потом су тај предмет после њега предавали проф. др Борис Марков, као лектор, и проф. др Војислав Илић (Илијашевић), као стални универзитетски наставник. Данас македонски језик предаје проф. др Првослав Радић. ${ }^{4}$ Наводи се да је први предавач за бугарски језик била Љиљана Мојсов, изабрана 1962. године, а наставу су држали уговорни лектори из Бугарске. Тренутно бугаристика на Катедри има више предавача у различитим звањима.

Посебно место у настави јужнословенских језика на Филолошком факултету у Београду, нарочито од 2006. године, са увођењем болоњске реформе, заузима словеначки језик. Специјална пажња у овом раду посвећена је управо словеначком језику, и то из два разлога: могућност студирања словеначког језика у трајању од четири године (за разлику од македонског језика) и огроман број студената који бирају предмете везане за словеначки (за разлику и од наставе македонског и од наставе бугарског језика). ${ }^{5}$

Почевши од 1958. године, први (хонорарни) наставник словеначког језика био је професор новосадског Универзитета др Рудолф Коларич. Током осамдесетих и деведесетих година прошлог века, практичну наставу словеначког језика изводили су лектори, а међу њима најдуже Катјуша Закрајшек. Теоријску наставу је изводио проф. др Живојин Станојчић, кога је наследила проф. др Маја Ђукановић.

Од 1947. године, па све до деведесетих година XX века, словеначки језик је имао статус обавезног предмета на две такозване "националне" катедре Филолошког факултета у Београду - на Катедри

3 Слична је ситуација и на Филозофском факултету у Новом Саду, где се словеначки и македонски језик изучавају при Одсеку за српски језик и лингвистику.

4 Више о настави македонског језика у Србији и статусу македонског генерално в. Бошњаковић (2007) и Књижар, Станковић и Бошњаковић (2013).

5 Подаци о историји предавања словеначког језика који се овде наводе преузети су из Ђукановић (2014а, 20146). 
за српски језик и јужнословенске језике, као и на Катедри за српску књижевност и југословенске књижевности. Међутим, најзначајнији помак у изучавању словеначког језика у Србији десио се почетком овог века. Од школске 2006/07. године на Филолошком факултету у Београду прва генерација студената почиње четворогодишње/ петогодишње студије словеначког језика на Катедри за општу лингвистику, где постоји могућност избора великог броја комбинација различитих предмета. Студије словеначког језика и културе могу се комбиновати са студијама опште лингвистике или са студијама било ког страног језика на Филолошком факултету. Од увођења нових предмета и могућности комбиновања студија словеначког језика и културе са другим студијским групама интересовање за словеначки језик, а пре свега за словеначку културу, међу студентима је достигло веома висок ниво. Уз многобројне и разноврсне догађаје у оквиру лектората, гостујуће предаваче, стручне екскурзије и стипендије, студенти имају могућност да науче словеначки језик на највишем нивоу. Они најуспешнији раде као предавачи и преводиоци, а знање словеначког језика им помаже да нађу запослење и у државним установама, словеначким представништвима, медијским и издавачким кућама.

Заслуга за овакав статус словеначког језика припада на првом месту Лекторату за словеначки језик и Катедри за општу лингвистику Филолошког факултета у Београду, али свакако и Центру за словеначки као други/страни језик са Филозофског факултета у љубљани, који свесрдно помаже наставу словеначког језика као страног у свету.

Универзитетска настава словеначког језика тренутно се одвија на око 60 универзитета широм света. Рад свих тих лектората, катедара или студијских група усмерава, подржава и координира Центар за словеначки као други/страни језик, који делује у оквиру Филозофског факултета Универзитета у Љубљани. У оквиру центра је, поред осталих активности, као што су осмишљавање и издавање наставних материјала, одржавање испита за странце и слично, високо развијен програм Словеначки језик на страним универзитетима. Он се не бави само језиком, већ води рачуна о целовитој промоцији словеначке културе. Посланство програма Словеначки језик на страним универзитетима не своди се само на организовање лектората словеначког језика и студија словенистике широм света, и успостављање и одржавање контаката са предавачима словеначког језика из иностранства, него 
је усмерено на промоцију словенистике, словеначке науке и културе, као и целе Словеније. У основи ове успешне организације лежи висока организованост, стручност запослених кадрова и жеља за промоцијом словеначког језика, књижевности и културе. Овај програм својим деловањем утиче и на успешно извођење наставе словеначког језика на београдском универзитету, а тиме и на формирање квалитетних стручних кадрова из области словенистике. ${ }^{6}$

\section{3. Могући правци развоја изучавања јужнословенских језика}

Савремена кретања у Европи иду у прилог изучавања јужнословенских језика, пре свега у оквиру студија два и више језика. Чињенице показујуда на тржишту рада постоји потреба за стручњацима овог профила, који се запошљавају као преводиоци у привреди, издавачким кућама, уредници у часописима, културним редакцијама свих врста медија, судски тумачи и као сарадници у научним институцијама.

У том смислу посебно би биле значајне две ствари. Прва је комбиновање студирања јужнословенских језика и то (по узору на бугарски и словеначки језик) на четворогодишњем нивоу, а друга ствар је комбиновање јужнословенских језика са другим језицима током студирања (по узору на словеначки језик). Могућност комбиновања јужнословенских језика током студирања (ако не сва три, макар по два језика) далеко би побољшало компентенције будућих студената и отворило им много веће могућности приликом запошљавања. Студирање пак једног јужнословенског језика у комбинацији са неким другим страним језиком такође би студентима нудило нове могућности у сваком погледу., као што је већ случај са комбиновањем студија словеначког језика и неког другог страног језика.

У вези са поменутим могућностима комбиновања, будући да на Филолошком факултету већ постоје квалификовани предавачи за све јужнословенске језике и књижевности, укључујући наравно и српски језик и књижевност, дијахроне дисциплине, као и упоредну граматику словенских и индоевропских језика, од посебног би значаја за Фи-

6 О организацији и деловању Центра за словеначки као други/страни језик и посебно о словеначком на страним универзитетима в. Нидорфер Шишкович $(2004 a, 20046,2008)$. 
лолошки факултет, Универзитет у Београду, па и Србију у целини, било оснивање неке врсте центра за изучавање јужнословенских језика, књижевности и културе. Ово би на првом месту било интересантно и корисно за стране студенте, којима је познавање јужнословенских језика, књижевности и културе потребно из различитих разлога. Ту се између осталих мисли и на оне студенте који имају мултидисциплинарна интересовања, где би се познавање јужнословенских језика, књижевности и културе могло спојити са историјом, географијом, економијом, етнологијом, политикологијом и слично.

Програм јужнословенксих студија требало би да буде и што отворенији за покретљивост и размену студената на међународном нивоу, као и друге различите активности које на занимљив и динамичан начин доприносе учењу јужнословенских језика. Овде се опет као пример може навести словеначки језик и делатност Центра за словеначки као други/страни језик. Важан део у активностима Центра представља међународна делатност програма Словеначки на страним универзитетима, односно мобилност студената и предавача, што омогућавају програми Socrates/Erasmus Европске уније и CEEPUS за Средњу Европу (Central European Exchange Programmes for University Studies). У Словенији овакве програме омогућава организација CMEPIUS, а академску размену подстиче и словеначка фондација Ad futura. ${ }^{7}$ Програм словеначки језик на страним универзитетима покрива и друге делатности, као што је помоћ у организацији стручних екскурзија у Словенији, организовање књижевних, музичких, кулинаричких и сличних вечери, гостовања словеначких писаца и културних радника у иностранству и слично. Све ове активности, примењене и на остале јужнословенске језике, значајно би допринеле не само унапређењу процеса наставе и учења ових језика, него би генерално утицале на популаризацију јужнословенских језика и култура.

\section{4. Закључак}

Изучавање јужнословенских језика (словеначког, македонског и бугарског) има дугу и значајну традицију у Србији, а пре свега на

7 Више в. у Нидорфер Шишкович (2008). 
Универзитету у Београду, односно Филолошког факултету. Посебно место заузима настава словеначког језика, књижевности и културе, будући да постоји могућност комбиновања, на четворогодишњем нивоу, са студијама опште лингвистике и другим страним језицима, као и узимајући у обзир велику заинтересованост студената за словеначке предмете, пре свега за словеначку културу.

Имајући у виду савремене тенденције у настави страних језика, књижевности и културе, и изучавање ових језика требало би да прати текуће иновације. Добар пример у том смеру је опет настава словеначког језика и на првом месту делатност Центра за словеначки као други/страни језик. Могућност комбиновања студирања јужнословенских језика међусобно, као и са другим страним језицима, пружила би додатну вредност изучавању ових језика, која има дугу и успешну традицију.

\section{Литература}

Бошњаковић, Жарко. „Поштујући туђе, чувамо своје! “. Јулијана Вучо (ур.).

Савремене тендениије у настави језика и књижевности. Београд: Филолошки факултет. 2007. 406-411.

Bukvič, Tatjana. „,Dopolnilni pouk slovenskega jezika in kulture v Republiki Srbiji: raziskava med učenci, starši in učiteljicami ". Slovenika II, (2016): 21-32.

Đukanović, Maja. „Slovenščina v Srbiji: preteklost, sedanjost in prihodnost“. Hotimir Tivadar (ur.). Prihodnost slovenščine in slovenistik po svetu. 50. SSJLK. Ljubljana: Znanstvena založba Filozofske fakultete. 2014a. 177-184.

Đukanović, Maja. „,Pouk slovenskega jezika in kulture v Srbiji“. Alenka DoležalováJensterle, Jansa Honzak Jahič, Andrej Šurla (ur.). Sto let slovenistiky na Univerzite Karlove v Praze: pedagogove a vedci ve stinu dejin. Vyd. 1. Praha: Filozoficka fakulteta Univerzity Karlovy. 20146. 405-411.

Књижар, Иван, Станислав Станковић и Жарко Бошњаковић. „Етнолингвистичка виталност македонске националне мањине у Републици Србији“. Македонски Јазик LXIV, (2013):117- 127.

Nidorfer Šiškovič, Mojca. „Slovenščina na tujih univerzah“. Jezik in slovstvo 49/3-4, (2004a): 163-165.

Nidorfer Šiškovič, Mojca. „Slovenščina na tujih univerzah in evropski izzivi = Slovene in universities abroad and European challenges". Glas 9/3, (2004b): 44-47.

Nidorfer Šiškovič, Mojca. „Program Slovenščina na tujih univerzah in slovenistike v Evropski uniji“. Ivšek, Milena (ur.). Jeziki v izobraževanju. Zbornik prispevkov konference (25-26. septembra 2008), Ljubljana: Zavod RS za šolstvo. 2008. 151-154. 


\section{Borko Kovačević \\ Maja Đukanović}

\section{TEACHING SOUTH SLAVIC LANGUAGES IN SERBIA AT UNIVERSITY LEVEL - HISTORY AND PROSPECTIVE DEVELOPMENT}

\section{Summary}

This paper presents the status of Slovenian, Macedonian and Bulgarian at university level of teaching in Serbia, specifically at Faculty of Philology in Belgrade. Starting with the history of the teaching of these languages, from the beginning of the $20^{\text {th }}$ century, their position within other foreign languages and minority languages is presented. Special emphasis is put on the prospective development of the studies of South Slavic languages, with all specifics that follow their status and mutual relationship. 